\title{
Some aspects on tick species in Mongolia and their potential role in the transmission of equine piroplasms, Anaplasma phagocytophilum and Borrelia burgdorferi L.
}

\author{
Myadagsuren Narankhajid ${ }^{1,2}$. Chultemsuren Yeruult ${ }^{2}$ - Agvaandaram Gurbadam ${ }^{2}$ - Jigjav Battsetseg ${ }^{3}$. \\ Stephan W. Aberle ${ }^{4}$. Badamdorj Bayartogtokh ${ }^{5}$ - Anja Joachim ${ }^{1} \cdot$ Georg Gerhard Duscher $^{1}$ (D)
}

Received: 5 February 2018 / Accepted: 13 August 2018 /Published online: 3 September 2018

(C) The Author(s) 2018

\begin{abstract}
Ticks are cosmopolitan vectors of numerous diseases, and detection of various pathogens in ticks can help to assess their distribution. In the current study, 528 adult ticks were collected from grazing animals or the ground in ten different Mongolian provinces. Dermacentor nuttalli constituted $76.1 \%$ of them and was found in all ecozones except the eastern desert. Dermacentor marginatus (8.3\%), Dermacentor silvarum (1.1\%) and Ixodes persulcatus $(3.0 \%)$ were found in the northern forest areas and Hyalomma asiaticum (11.4\%) only in the southern (semi-)desert. Of these, 359 ticks were subjected to DNA extraction and PCR was carried out to detect various pathogens. Anaplasma spp. was found in D. marginatus and D. nuttalli (2.5\% positive each), including flagged specimen and identified as Anaplasma phagocytophilum. Borrelia spp. were found in $2.5 \%$ of the ticks (mostly in I. persulcatus) and identified as Borrelia garinii. Babesia spp. (40\%) identified as Babesia caballi were detected in all five tick species including flagged Dermacentor spp. and I. persulcatus, and 3.5\% of the ticks (all species except D. silvarum) were positive for Theileria spp. identified as Theileria equi. The piroplasms were found in all provinces. Tick-borne encephalitis virus was not detected. The results highlight the high risk of equine piroplasmosis in Mongolia, which is a concern for both the nomadic population who rely on horses for transport and for conservation of Przewalski's horses in Mongolia. In addition, zoonotic agents such as the avian B. garinii and A. phagocytophilum were also detected, outlining a high risk for exposed humans.
\end{abstract}

Keywords Anaplasmosis $\cdot$ Borreliosis $\cdot$ Piroplasmosis $\cdot$ TBE $\cdot$ Horses $\cdot$ Ixodid ticks

Georg Gerhard Duscher

Georg.Duscher@vetmeduni.ac.at

Myadagsuren Narankhajid

narankhajid@mnums.edu.mn

Chultemsuren Yeruult

eruultch@mnums.edu.mn

Agvaandaram Gurbadam

gurbadam@nmums.edu.mn

Jigjav Battsetseg

jigjavb@gmail.com

Stephan W. Aberle

stephan.aberle@meduniwien.ac.at

Badamdorj Bayartogtokh

bayartogtokh@num.edu.mn
Anja Joachim

Anja.Joachim@vetmeduni.ac.at

1 Institute of Parasitology, Department of Pathobiology, University of Veterinary Medicine Vienna, Veterinaerplatz 1, 1210 Wien, Austria

2 Mongolian National University of Medical Sciences, S. Zorig Street 3, Ulaanbaatar 14210, Mongolia

3 National Centre for Zoonotic Diseases, Ministry of Health, Songinokhairkhan 20, Ulaanbaatar 14219, Mongolia

4 Department of Virology, Medical University of Vienna, Kinderspitalgasse 15, 1095 Vienna, Austria

5 Department of Biology, National University of Mongolia, Zaluuchuud Avenue 1, Ulaanbaatar 14201, Mongolia 


\section{Introduction}

Ticks are notorious vectors of various pathogens that cause serious and life-threatening infections in humans and animals worldwide (Estrada-Peña and Jongejan 1999; Parola and Raoult 2001; Zhang 2012; Wu et al. 2013). In many cases, screening of ticks for such pathogens with molecular tools can identify their presence in particular geographic regions. While a number of these agents primarily pose a threat to animal health, such as Theileria spp. and Babesia spp., the agents of piroplasmosis in various animals (Krause 2002; Irwin 2010; Suarez and Noh 2011; Wise et al. 2013; Beugnet and Moreau 2015; Alvarado-Rybak et al. 2016; Solano-Gallego et al. 2016; Tarav et al. 2017), can harm both animals and humans, for instance Anaplasma phagocytophilum, the causative agent of human granulocytic anaplasmosis (Stuen et al. 2013), Borrelia burgdorferi sensu lato which causes Lyme disease and is considered an emerging or spreading disease worldwide (Stone et al. 2017; Strnad et al. 2017). Tick-borne encephalitis virus (TBEV) is one of the most important causes of inflammatory disease on the central nervous system in humans in Europe and Asia (including Mongolia; Khasnatinov et al. 2010) which is also considered to be an emerging disease (Jaenson et al. 2012; Valarcher et al. 2015); it has a wildlife reservoir and also can infect dogs and cats (Duscher et al. 2014).

In central Asian countries including Mongolia, the abovementioned tick-borne pathogens have previously been detected in ticks by DNA analysis or in mammals by direct or indirect detection methods. Anaplasma spp. and Borrelia spp. were detected in Mongolian ticks (Fomenko et al. 2009; Scholz et al. 2013; Masuzawa et al. 2014; Iwabu-Itoh et al. 2017; Javkhlan et al. 2014), livestock (Papageorgiou et al. 2012; Karnath et al. 2016; Ochirkhuu et al. 2017) and humans (Walder et al. 2006; von Fricken et al. 2018). Piroplasms were detected in ticks (Battsetseg et al. 2001, 2002; Boldbaatar et al. 2005; Tuvshintulga et al. 2015, 2016; Karnath et al. 2016), livestock (Avarzed et al. 1997; Ruegg et al. 2007; Altangerel et al. 2011, 2012; Sivakumar et al. 2012; Munkhjargal et al. 2013; Yoshinari et al. 2013) and humans (Hong et al. 2014) in Mongolia. TBEV was isolated from ticks (Frey et al. 2012) and detected in humans in Mongolia (Walder et al. 2006; Khasnatinov et al. 2010; Muto et al. 2015). However, most of these studies were limited in sample size, the pathogens detected or geographical coverage and most of them did not consider multiple infections in ticks.

Mongolia is known for its pastoral animal husbandry where the local herders raise more than 61 million livestock (National Statistical Office of Mongolia 2017; http://www. en.nso.mn), which constitutes a major resource for their economy. Since animal husbandry is based on a nomadic lifestyle, domestic and wild animals are frequently in both direct and indirect contact because they share the same pastures and water sources, and cross-infection can easily occur. Prevention of the spread of infections, including zoonotic diseases, is therefore highly important in this country.

The goal of the present preliminary investigation was to evaluate the frequency of tick species from different areas of Mongolia and of the pathogens they harbour to provide data for a disease risk assessment for several important tick-borne diseases (anaplasmosis, borreliosis, equine piroplasmosis and tick-borne encephalitis).

\section{Materials and methods}

\section{Study area}

Mongolia is a landlocked country in eastern and central Asia with around 3.1 million inhabitants. It borders Russia to the north and the People's Republic of China to the south, east and west. The land area of Mongolia $\left(1.564 .116 \mathrm{~km}^{2}\right.$ or 603,909 square miles; www.wikipedia.com) is divided into 21 provinces (aimags) with 334 districts. The country contains very little arable land, as much of its area is covered by steppes, with mountains to the north and west and the Gobi Desert to the south. Approximately 30\% of Mongolia's population is nomadic, and pastoral herders spend prolonged periods with their livestock. This close proximity to animals and working outdoors increases the potential for exposure to ticks and the pathogens they harbour for humans, which can directly impact the lives of Mongolians by causing illness and indirectly through economic losses incurred from illness in livestock (von Fricken et al. 2018). Distributions, abundance, habitat preference of ticks in various regions and ecosystems of Mongolia and their vertebrate host spectrum have been described previously (Dash et al. 1988; Danchinova et al. 2007, 2012).

\section{Sample collection}

A total of 528 adult ticks were collected from domestic animals and by flagging from the environment in ten different provinces (Bayankhongor, Gobi-Altai, Huvsgul, Selenge, Bulgan, Dornogobi, Hovd, Zavkhan, Tuv and Arkhangai provinces) covering the western, northern and southern parts of Mongolia (Fig. 1, Tables 1 and 2). Specifically, horses were sampled in four provinces (Gobi-Altai, Bulgan, Hovd and Tuv). The ticks were identified according to standard taxonomic keys (Schulze and Schlottke 1930; Khishigsuren 2002).

\section{DNA extraction, PCR amplification and sequence analysis}

Adult ticks were air-dried on microscope slides for $5 \mathrm{~min}$ to allow excess ethanol to evaporate and dissected lengthwise 


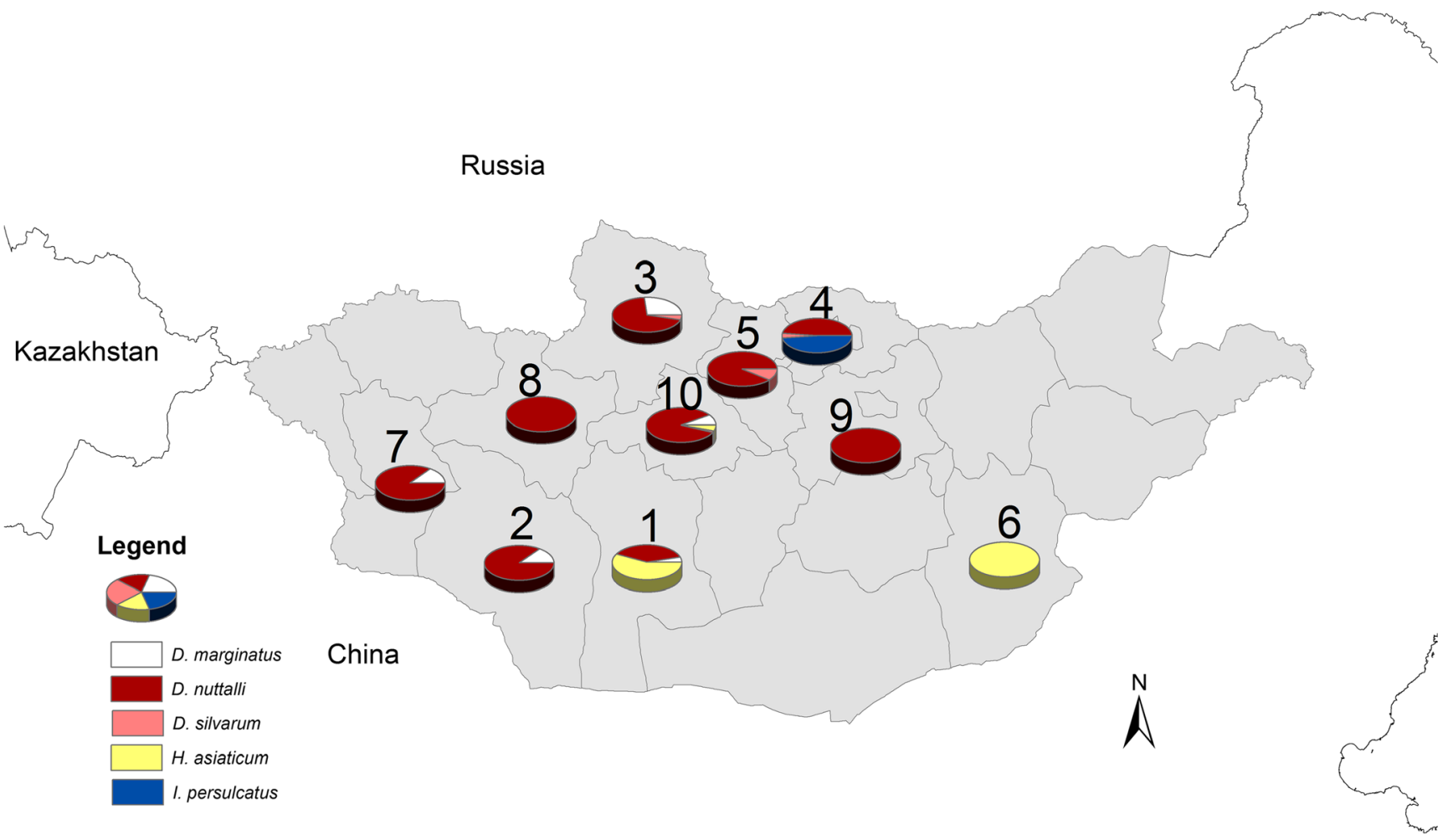

Fig. 1 Ticks collected from 10 provinces in Mongolia. 1 = Bayankhongor $(n=84), 2=$ Gobi-Altai $(n=82), 3=\operatorname{Huvsgul}(n=60), 4=$ Selenge $(n=$

Zavkhan $(n=40), 9=$ Tuv $(n=40)$ and $10=$ Arkhangai $(n=80)$ 33), $5=$ Bulgan $(n=24), 6=$ Dornogobi $(n=13), 7=\operatorname{Hovd}(n=72), 8=$ provinces. Tick species are indicated with pie sections of different colours

Table 1 Distribution of tickborne pathogens in different provinces of Mongolia

\begin{tabular}{llllll}
\hline \multirow{2}{*}{ Province } & Ticks collected/examined $(n)$ & \multicolumn{2}{l}{ Number $(\%)$ of PCR-positive samples } & \\
\cline { 3 - 6 } & & Anaplasma & Borrelia & Babesia & Theileria \\
\hline 1. Bayankhongor & $84 / 64$ & 0 & 2 & 27 & 0 \\
2. Gobi-Altai & $82 / 61$ & $2^{\mathrm{a}}$ & 2 & 27 & 0 \\
3. Huvsgul & $60 / 49$ & $7^{\mathrm{b}}$ & 0 & 31 & 0 \\
4. Selenge & $33 / 11$ & 0 & $3^{\mathrm{c}}$ & 5 & 1 \\
5. Bulgan & $24 / 17$ & 0 & 0 & 12 & $2^{\mathrm{f}}$ \\
6. Dornogobi & $13 / 8$ & 0 & 0 & $3^{\mathrm{d}}$ & 1 \\
7. Khovd & $72 / 45$ & 0 & 1 & 20 & $8^{\mathrm{g}}$ \\
8. Zavkhan & $40 / 20$ & 0 & 0 & 6 & 0 \\
9. Tuv & $40 / 27$ & 0 & 1 & 3 & 0 \\
10. Arkhangai & $80 / 58$ & 0 & 0 & $11^{\mathrm{e}}$ & 1 \\
Total & $528 / 360$ & $9(2.5 \%)$ & $9(2.5 \%)$ & $145(40.3 \%)$ & $13(3.6 \%)$ \\
\hline
\end{tabular}

Sequence confirmations (in parentheses: number of specimen):

${ }^{\mathrm{a}}$ A. phagocytophilum $\mathrm{G}$ variant from $D$. nuttalli, feeding on sheep (1) and goat (1)

${ }^{\mathrm{b}}$ A. phagocytophilum $\mathrm{G}$ variant from questing D. marginatum (1), A. phagocytophilum A variant from questing D. nuttalli (6)

${ }^{\mathrm{c}}$ B. garinii from questing I. persulcatus (2)

${ }^{\mathrm{d}}$ Ba. caballi from $H$. asiaticum attached to camel (1)

${ }^{\mathrm{e}}$ Ba. caballi from $D$. nuttalli attached to goat (1)

${ }^{\mathrm{f}}$ T. equi from $D$. nuttalli feeding on sheep (2)

${ }^{\mathrm{g}}$ T. equi from D. nuttalli feeding on horses (4) 
Table 2 Patterns of infestation by adult ticks and tick-borne pathogens for different vertebrate hosts and the environment in the study provinces

\begin{tabular}{|c|c|c|c|c|c|c|c|c|}
\hline \multirow{2}{*}{$\begin{array}{l}\text { Host } \\
\text { (source) }\end{array}$} & \multirow[t]{2}{*}{ Tick species } & \multirow{2}{*}{$\begin{array}{l}\text { Number of } \\
\text { collected ticks }\end{array}$} & \multirow{2}{*}{$\begin{array}{l}\text { DNA extraction } \\
\text { positive ticks }\end{array}$} & \multirow[t]{2}{*}{ Infected ticks } & \multicolumn{4}{|c|}{ Detected pathogens infecting ticks by PCR } \\
\hline & & & & & Anaplasma & Borrelia & Babesia & Theileria \\
\hline \multirow[t]{4}{*}{ Camel } & D. marginatus & 7 & 2 & 2 & 0 & 0 & 2 & 0 \\
\hline & D. nuttalli & 41 & 30 & 10 & 0 & 1 & 9 & 0 \\
\hline & H. asiaticum & 16 & 15 & 8 & 0 & 1 & 6 & 1 \\
\hline & Subtotal & 64 & 47 & 20 & 0 & 2 & 17 & 1 \\
\hline \multirow[t]{4}{*}{ Horse } & D. marginatus & 3 & 3 & 4 & 0 & 0 & 2 & 2 \\
\hline & D. nuttalli & 40 & 25 & 23 & 0 & 1 & 15 & 7 \\
\hline & D. silvarum & 2 & 0 & 0 & 0 & 0 & 0 & 0 \\
\hline & Subtotal & 45 & 28 & 27 & 0 & 1 & 17 & 9 \\
\hline \multirow[t]{4}{*}{ Sheep } & D. marginatus & 5 & 4 & 1 & 0 & 0 & 1 & 0 \\
\hline & D. nuttalli & 85 & 58 & 29 & 1 & 1 & 26 & 1 \\
\hline & H. asiaticum & 5 & 5 & 2 & 0 & 0 & 2 & 0 \\
\hline & Subtotal & 95 & 67 & 32 & 1 & 1 & 29 & 1 \\
\hline \multirow[t]{4}{*}{ Goat } & D. marginatus & 10 & 9 & 4 & 0 & 0 & 4 & 0 \\
\hline & D. nuttalli & 113 & 87 & 31 & 1 & 2 & 28 & 0 \\
\hline & H. asiaticum & 33 & 23 & 8 & 0 & 0 & 8 & 0 \\
\hline & Subtotal & 156 & 119 & 43 & 1 & 2 & 40 & 0 \\
\hline \multirow[t]{5}{*}{ Cattle } & D. marginatus & 3 & 1 & 0 & 0 & 0 & 0 & 0 \\
\hline & D. nuttalli & 62 & 36 & 6 & 0 & 0 & 5 & 1 \\
\hline & D. silvarum & 1 & 0 & 0 & 0 & 0 & 0 & 0 \\
\hline & H. asiaticum & 6 & 1 & 1 & 0 & 0 & 1 & 0 \\
\hline & Subtotal & 72 & 38 & 7 & 0 & 0 & 6 & 1 \\
\hline \multirow[t]{2}{*}{ Human } & D. nuttalli & 2 & 1 & 0 & 0 & 0 & 0 & 0 \\
\hline & Subtotal & 2 & 1 & 0 & 0 & 0 & 0 & 0 \\
\hline \multirow[t]{5}{*}{ Field } & D. marginatus & 16 & 16 & 8 & 1 & 0 & 7 & 0 \\
\hline & D. nuttalli & 59 & 35 & 31 & 6 & 1 & 24 & 0 \\
\hline & D. silvarum & 3 & 2 & 1 & 0 & 0 & 1 & 0 \\
\hline & I. persulcatus & 16 & 7 & 7 & 0 & 2 & 4 & 1 \\
\hline & Subtotal & 94 & 60 & 47 & 7 & 3 & 36 & 1 \\
\hline \multicolumn{2}{|l|}{ Total } & 528 & 360 & $176(48.9 \%)$ & $9(2.5 \%)$ & $9(2.5 \%)$ & $145(40.3 \%)$ & $13(3.6 \%)$ \\
\hline \multicolumn{2}{|c|}{ Sequences obtained } & & & & $9(100 \%)$ & $2(22.2 \%)$ & $36(24.8 \%)$ & $9(69.2 \%)$ \\
\hline
\end{tabular}

with sterile scalpel blades. Half of the tick was used for DNA isolation with the DNeasy tissue kit (QIAGEN GmbH, Germany) according to the manufacturer's instructions. Isolated DNA was eluted in $100 \mu \mathrm{AE}$ buffer (QIAGEN $\mathrm{GmbH}$ ) and aliquots were frozen immediately at $-80{ }^{\circ} \mathrm{C}$ for subsequent analysis.

For molecular identification of tick-borne pathogens, PCR was performed on a Biometra T-Gradient thermocycler using primers and cycling conditions as described in Table 3. Each reaction $(25 \mu \mathrm{l})$ contained $5 \mu \mathrm{l}$ of template DNA, $5 \mu \mathrm{l}$ of $5 \times$ Green $\mathrm{GoTaq}^{\circledR}$ reaction buffer (Promega, Mannheim, Germany) $200 \mu \mathrm{M}$ of each dNTP and $0.75 \mathrm{U} \mathrm{GoTaq}^{\circledR}$ DNA polymerase (Promega). A negative control with distilled water instead of template DNA and positive controls (DNA of Anaplasma, Borrelia, Theileria or Babesia) were included in each run.

PCR products were separated using an ethidium bromidestained 2\% agarose gel (2:1 sieve agarose; Biozym, Austria) in Tris-acetate-EDTA buffer and visualised under UV light. A
DNA molecular weight marker (Promega) was used to estimate product sizes. The positive PCR products were purified (QIAquick PCR Purification kit, QIAGEN GmbH, Germany) according to the manufacturer's instructions, and the purified products were sent to Microsynth AG for sequence determination (Sanger Sequencing Division, Switzerland).

Sequences were assembled and edited with AlignPlus ${ }^{\circledR}$ software (version 4.1). Sequences obtained in the present study were compared with the corresponding sequences deposited in GenBank ${ }^{\circledR}$ by using the BLAST software of the National Center for Biotechnology Information (https://blast. ncbi.nlm.nih.gov/Blast.cgi).

\section{Data analysis}

Data were analysed using SPSS 14.0 software. Correlations were calculated using Pearson's and Spearman's rank correlation coefficients. 
Table 3 Primers used for PCR for the detection and identification of tick-borne pathogens in ticks from Mongolia

\begin{tabular}{|c|c|c|c|c|c|c|}
\hline Target genus of species & $\begin{array}{l}\text { Target } \\
\text { gene }\end{array}$ & $\begin{array}{l}\text { Forward primer }\left(5^{\prime}-3^{\prime}\right) \\
\text { Reverse primer }\left(3^{\prime}-5^{\prime}\right)\end{array}$ & $\begin{array}{l}\text { Annealing } \\
\text { temp. }\left({ }^{\circ} \mathrm{C}\right)\end{array}$ & $\begin{array}{l}\text { No. of } \\
\text { cycles }\end{array}$ & $\begin{array}{l}\text { Expected } \\
\text { amplicon } \\
\text { size (bp] }\end{array}$ & References \\
\hline Anaplasma spp. & groESL & $\begin{array}{l}\text { AGACGAAATTGCACAAGTT } \\
\text { AGCCTTTGCTTTCTTCAAC }\end{array}$ & 64 & 55 & 128 & Polin et al. 2004 \\
\hline Borrelia spp. & rpoB & $\begin{array}{l}\text { GATGATATTGACCATTTAGG } \\
\text { TTCAGGGGTTTCAATAGGAC }\end{array}$ & 63 & 40 & 369 & Lee et al. 2000 \\
\hline Babesia spp. & 18S rRNA & $\begin{array}{l}\text { GACTAGGGATTGGAGGTC } \\
\text { GAATAATTCACCGGATCACTC }\end{array}$ & 53 & 30 & 650 & Blaschitz et al. 2008 \\
\hline Theileria spp. & 18S rRNA & $\begin{array}{l}\text { TGACACAGGGAGGTAGTGA } \\
\text { TCAGCCTTGCGACCATACT }\end{array}$ & 60 & 35 & 1590 & Sawczuk et al. 2008 \\
\hline
\end{tabular}

Nucleotide sequence accession numbers The 18S rRNA gene sequences of Babesia caballi are available at GenBank ${ }^{\circledR}$ [GenBank: JQ288735 and JQ288736]. The 18S rRNA gene sequences of Theileria equi is available at GenBank ${ }^{\circledR}$ [GenBank: JQ657703]. The RNA polymerase beta subunit gene sequence of Borrelia garinii is available at GenBank ${ }^{\circledR}$ [GenBank: JQ657704]. The sequences for A. phagocytophilum were too short for submission.

\section{Results}

\section{Ticks}

In total, 528 adult ticks ( 244 females and 284 males) collected from ten different provinces located in various ecological areas were attributed to five species from three genera of different abundancies (Fig. 1 and Table 4). The distribution of species varied in different ecozones. Dermacentor nuttalli (76.1\%) was found in all ecological zones (according to the Köppen-Geiger classification; https:/en.wikipedia.org/wiki/ K\%C3\%B6ppen_climate_classification) except the most eastern desert (Dornogobi province). It was the only species collected in the grassland areas of Tuv and Arkhangai.
Dermacentor marginatus (8.3\%) was collected from taigaforest and forest-steppe of the northern, central and western areas; it was most frequent in the northern Huvsgul province. Dermacentor silvarum (1.1\%) was only found in the foreststeppe of the northern Bulgan province. Ixodes persulcatus $(3.0 \%)$ was collected only in the northern taiga-forest and forest-steppe of Selenge province. Hyalomma asiaticum $(11.4 \%)$ was found in the desert and semi-desert ecosystems in the south and south-east (Dornogobi, where only eight specimen of this species were collected) and was the dominating species of these areas (Fig. 1; Table 1). All tick species except $H$. asiaticum could be flagged from the ground; this species was removed from camel and ruminants only (Table 2).

\section{DNA analysis}

DNA extraction was successful in only $360(68.2 \%)$ of the ticks, most probably due to prolonged and unsuitable storage and transportation conditions. Similarly, sequences could only be obtained in completeness for all A. phagocytophilum-positive samples, while rpoB (Borrelia species determination) and $18 \mathrm{~S}$ rDNA (for piroplasms) sequence determinations were only partially successful.

Table 4 Distribution of infections by tick species, including multiple infections

\begin{tabular}{|c|c|c|c|c|c|c|}
\hline & D. marginatus & D. nuttalli & D. silvarum & I. persulcatus & H. asiaticum & All species \\
\hline$N$ ticks (\% of all specimen) & $44(8.3)$ & $402(76.1)$ & $6(1.1)$ & $16(3.0)$ & $60(11.4)$ & 528 \\
\hline$N$ ticks with DNA extraction (\%) & $35(79.5)$ & $272(67.6)$ & $2(33.3)$ & $7(43.8)$ & $44(73.3)$ & $360(68.2)$ \\
\hline Infected ticks (\%) & 54.3 & 48.0 & 50.0 & 100 & 43.2 & 48.9 \\
\hline Anaplasma positive in (\%) & 2.9 & 3.0 & 0.0 & 0.0 & 0.0 & 2.5 \\
\hline Borrelia positive (\%) & 0.0 & 2.2 & 0.0 & 28.6 & 2.3 & 2.5 \\
\hline Babesia positive $(\%)$ & 45.7 & 39.5 & 50.0 & 57.1 & 38.6 & 40.3 \\
\hline Theileria positive (\%) & 5.7 & 3.3 & 0.0 & 14.3 & 2.3 & 3.6 \\
\hline Anaplasma + Babesia positive (\%) & 0.0 & 3.7 & 0.0 & 0.0 & 0.0 & 2.8 \\
\hline Borrelia + Babesia positive $(\%)$ & 0.0 & 1.1 & 0.0 & 28.6 & 2.3 & 1.7 \\
\hline Theileria + Babesia positive $(\%)$ & 5.7 & 2.2 & 0.0 & 14.3 & 2.3 & 2.8 \\
\hline
\end{tabular}


Nine ticks, collected in the Gobi-Altai and Huvsgul provinces, were positive for Anaplasma spp. by PCR (Table 1). $D$. nuttalli and $D$. marginatus collected from sheep, goats, or the field (D. marginatus, D. nuttalli) were positive (Table 2). The 126-bp region of the A. phagocytophilum heat shock operon groESL gene was amplified from each positive specimen and was $100 \%$ homologous to A. phagocytophilum sequences from Russia, Spain, France and Slovenia [GenBank ${ }^{\circledR}$ accession numbers HQ629910, HM057232, EU860091 and EU381150]. Six amplicons (all derived from field-collected D. nuttalli from the Huvsgul province) could be identified as groSEL-A variants, three (two $D$. nuttalli from the Gobi-Altai region collected from sheep and goat, respectively, and one from a questing $D$. marginatus from Huvsgul) were groSEL-G variants.

The nine Borrelia-positive I. persulcatus and D. nuttalli were collected from goats, sheep, camel, horses or the field (Table 2) in five different provinces with prevalence rates of 2.2-3.7\% for Hovd, Bayankhongor, Gobi-Altai and Tuv and $27.3 \%$ in Selenge (Table 1). For two of the positive isolates (from questing I. persulcatus in Selenge), rроB gene sequences could be obtained and revealed $>99 \%$ similarity with B. garinii $\left[\right.$ GenBank $^{\circledR}$ accession numbers AF164225, AF164221 and AF164224] with the highest level of similarity to $B$. garinii IP89 strain from Korea [GenBank ${ }^{\circledR}$ accession number AF164225].

Babesia spp. were detected in 145 ticks of all five species in all provinces with prevalences from $11.1 \%$ in Tuv to $70.6 \%$ in Bulgan province (Tables 1 and 2). Positive ticks were collected from grazing animals or the field (questing Dermacentor spp. and I. persulcatus; Table 2). Only two $18 \mathrm{~S}$ rRNA gene sequences could be obtained, one from $H$. asiaticum from (camel in Dorngobi) and one from D. nuttalli (a goat in Arkhangai). Both were $98-100 \%$ similar to $B a$. caballi from Africa and Spain [GenBank ${ }^{\circledR}$ accession numbers Z15104, E888904, Z15105, DQ287954, AY150062 and AY150063].

Thirteen ticks from five provinces (prevalences 1.7-17.8\%; Table 1) collected from sheep, horses, cattle, camels and the field were positive for Theileria (Tables 2 and 4). In particular, $D$. marginatus and $D$. nuttalli from horses and one questing $I$. persulcatus were positive for Theileria. The five amplicons obtained 18S rRNA gene sequence (1590 bp) were > 99\% similar with T. equi [GenBank $^{\circledR}$ accession numbers HM229408, HM229407, DQ287951 and AY534882]. The sequences were all derived from $D$. nuttalli (three from horses in Hovd and one from a horse and one from a sheep in Bulgan). No TBEV nucleic acids could be detected by PCR in any of the examined ticks.

Multiple infections were diagnosed in 26 ticks of all species except $D$. silvarum. Ten $D$. nuttalli were positive for Anaplasma and Babesia, six ticks from three different species were positive for Borrelia and Babesia, and four different species for Theileria and Babesia (Table 4). Differences in the prevalence rates of mixed infections were not observed between the study provinces (details not shown).

\section{Discussion}

\section{Distribution of ticks and their possible roles as vectors}

In the present study, 528 adult ticks from ten Mongolia's provinces were determined to species level and 360 of them were analysed for different tick-borne pathogens. The most abundant species was $D$. nuttalli with constituted $76.1 \%$ of the ticks and was also the most widely distributed. In the present study, $D$. nuttalli was found in all ecological zones except the most eastern desert area (Dornogobi province) as reported earlier (Dash et al. 1988; Danchinova et al. 2007, 2012). Of the $271 \mathrm{D}$. nuttalli from which DNA could be extracted, $46.1 \%$ were infected with Anaplasma, Borrelia or piroplasms and the finding of these pathogens (with the exception of Theileria) in questing specimen of $D$. nuttalli highlights the possible role of this tick species as a vector of both human and animal pathogens as it was also the only species found on all animals as well as humans. Specifically, D. nuttalli is a well-known vector for equine piroplasms (Battsetseg et al. 2002, 2001; Scoles and Ueti 2015); however, in this study, sequences of $B a$. caballi and $T$. equi could only be confirmed in feeding ticks (six $D$. nuttalli and one $H$. asiaticum) and the exact percentage of these species in the ticks could not be determined.

The second most common tick species was $H$. asiaticum which had a rather restricted range in (semi-)arid areas, in accordance with earlier works (Dash et al. 1988) and a recent study by Boldbaatar et al. (2017); $43.2 \%$ of the examined specimens were positive for Borrelia or piroplasms. A number of Hyalomma spp. have been described as vectors for pirolasms of equids (see Scoles and Ueti 2015, for review) and bovine Theileria annulata in the Middle East (Mazlum 1968) but $H$. asiaticum was not known to transmit piroplasms so far. The presence of $B a$. caballi in one $H$. asiaticum specimen feeding on a camel does not sufficiently support this assumption since vector competence cannot be determined in feeding ticks. As Hyalomma specimen are difficult to flag (Duscher, unpublished) no ticks of this species could be collected from the environment and the definitive vector capacity still remains to be determined.

D. marginatus, the ornate sheep tick, is a tick species with a wide distribution in Eurasia (Rubel et al. 2016). This species is common in the forest-steppe and steppe pasturelands of central, northern, western and southwestern areas of Mongolia (Dash et al. 1988), but of low abundance in the present study, with $54.3 \%$ of the examined specimens being positive for Anaplasma spp., Borrelia spp. or piroplasms. It can transmit a number of pathogens and has already been inferred as vector of equine piroplasms (Scoles and Ueti 2015) but final determination if this is still lacking. Besides D. nuttalli, D. marginatus was the only tick species infected with Anaplasma which includes questing ticks so the vector role of these two species must be assumed. In the present study, only A. phagocytophilum could be detected by PCR and the role of these ticks as vectors for other Anaplasma 
spp. present in Mongolian livestock (Ochirkhuu et al. 2017) could not be determined here.

I. persulcatus, the taiga tick is abundantly distributed in the Siberian taiga-forest and forest-steppe areas of northcentral, northwestern and northeastern parts of Mongolia (Danchinova et al. 2007). It constituted only $3.0 \%$ of the collected ticks, but can nevertheless be considered a major vector of various pathogens. It not only transmits A. phagocytophilum in the northern areas of Mongolia (Javkhlan et al. 2014; Masuzawa et al. 2014; Karnath et al. 2016), but also borreliae (Kurtenbach et al. 2006; Fomenko et al. 2009) including the bird-associated B. garinii identified in the present study. It is the most important vector of TBEV in Mongolia (Baasandavga et al. 2017). In the present study, TBEV could not be detected in ticks, which is not surprising as other methods of surveillance are generally considered to be more sensitive (Stefanoff et al. 2013; Imhof et al. 2015). The vectorial role of $I$. persulcatus in Mongolia also includes the zoonotic microorganisms Babesia sp. "venatorum" (known also as Babesia sp. EU1) and Candidatus Neoehrlichia mikurensis (Karnath et al. 2016), so it must be considered as significant for human health (see also Jaenson et al. 2016, for review on the vector capacity of I. persulcatus), despite of the small number of ticks collected and its presumably restricted geographical location in Mongolia, as described previously (Filippova 1985; Boldbaatar et al. 2017). At a global scale, I. persulcatus is widely distributed and is considered to be spreading westwards (Jaenson et al. 2016).

According to Danchinova et al. (2007), D. silvarum occurs primarily in central and northern Mongolia in low abundance. D. silvarum was only sporadically detected in the present study in a single province; one of the two analysed specimens was positive for Babesia, as were the other, more abundant representatives of this genus. This does not allow for assessment of the role of this species as vector for the pathogens in question.

\section{Tick-borne pathogens}

Babesia and Theileria were the most frequently detected pathogens in this study. T. equi and Ba. caballi both infect the red blood cells of horses and cause similar systemic diseases with high mortalities of up to 50\% (de Waal 1992; de Waal and van Herden 1994; Wise et al. 2013; Beugnet and Moreau 2015). Due to the wide distribution of available tick vectors with high rates of piroplasms detected by PCR in Mongolia, equine piroplasmosis remains a significant threat to the health of horses also in this part of the world. Ba. caballi is the most commonly reported agent of horse babesiosis in the central, eastern and western regions of Mongolia (Avarzed et al. 1997; Xuan et al. 1998; Battsetseg et al. 2002; Boldbaatar et al. 2005). It was found in questing ticks of all detected tick species in all provinces and its prevalence was higher in ticks from horses $(64.2 \%)$ than in ticks from other grazing animals (15.8-51.7\%). T. equi was only detected in a single questing specimen of I. persulcatus, a tick that has not previously been reported to be a vector for this protozoal pathogen (de Waal and van Herde 1994; Scoles and Ueti 2015). It was also detected in Dermacentor spp. from horses as well as from $H$. asiaticum and $D$. nuttalli feeding on non-permissive hosts so a vector role can be assumed for these species. Equine husbandry in Mongolia has remained a pastoral nomadic system, which includes seasonal migrations and rotations of migration routes. Movement through endemic areas may contribute to infestation of horses with Dermacentor spp. and infections with T. equi and Ba. caballi (Battsetseg et al. 2001).

The prevalence rates for the two species in horses vary in different studies. Seropositivity was reported to be $51.6-84.5 \%$ for Ba. caballi and 19.6-88.2\% for T. equi with mixed infections in $10.4 \%$. PCR detected Ba. caballi in up to $20.0 \%$ of examined horses and T. equi in up to $92.7 \%$; mixed infections were < 3\% (Avarzed et al. 1997; Xuan et al. 1998; Sloboda et al. 2011; Munkhjargal et al. 2013; Tarav et al. 2017). Differences in the detection rates in horses are presumed to be a result of different transmission dynamics of the two parasites (despite concomitant detection of both parasite species in questing ticks; ref. this study and Battsetseg et al. 2001, 2002). In addition, parasitaemia for T. equi is considered to be much longer than that of Ba. caballi, and Ba. caballi-infected horses may therefore be seropositive without being infected anymore (Ruegg et al. 2006). Reintroduced Przewalski's horses (takhis) showed $84 \%$ positivity for $T$. equi, which is a concern since this parasite is responsible for mortalities of up to $19 \%$ in young wild horses (Tarav et al. 2017).

In addition to animal pathogens such as equine piroplasms, zoonotic agents such as A. phagocytophilum and B. garinii were found in considerable rates in the examined ticks, indicating that not only animals but also humans bear a high risk of infection when exposed to ticks which is common for nomads in Mongolia (Papageorgiou et al. 2012; von Fricken et al. 2018).

Anaplasma phagocytophilum has previously been detected in I. persulcatus as described above; it is a cosmopolitan pathogen and the causative agent of granulocytic ehrlichiosis worldwide. Its main vectors are Ixodes spp. (Stuen et al. 2013) but it has also been found in Haemaphysalis spp., D. nuttalli and D. silvarum in China (Wei et al. 2016). In the present study, Anaplasma was not detected in I. persulcatus, most likely due to the small sample size for this tick. Sequence analysis of the groESL genes of nine samples in this study revealed that six sequences were $100 \%$ identical to the $A$. phagocytophilum groESL-A variant mostly found in wild ungulates (Liz et al. 2002; Petrovec et al. 2003), three were $100 \%$ identical to the groESL-G variant primarily found in horses (Sumner et al. 1997; Loewenich et al. 2003), dogs (Smrdel et al. 2009) and humans (Sumner et al. 1997).

Lyme borreliae are widespread in Russia (Korenberg 1995; Nataliya et al. 2008) and China, with B. garinii as the main genotype, distributed mainly in its northern part (Wu et al. 
2013). This species was also detected in two questing $I$. persulcatus from Selenge.

Coinfections were detected mainly with Babesia spp. in line with the relative detection rates for the pathogens in different ticks, as described previously for Asian I. persulcatus (Masuzawa et al. 2014; Karnath et al. 2016; Boldbaatar et al. 2017). Overall, 26/176 (14.8\%) positive ticks were coinfected with two pathogens. An increasing number of studies report that ticks and their vertebrate hosts often harbour multiple infections, suggesting that this might be the rule rather than the exception (Belongia 2002; Swanson et al. 2006; Ginsberg 2008; Raileanu et al. 2017), and hosts infected with several pathogens may show more severe symptoms of diseases (Krause 2002; Pañczuk et al. 2016; Kaewmongkol et al. 2017).

Since Babesia-positive samples were quite frequent and products were not cloned to detect multiple infections, it is possible that infections with more than one piroplasmid species remained undetected and the number of multiple infections was underestimated. More detailed studies on piroplasmid infections should be carried out in future works to decipher any hidden or masked pathogens of this taxon.

Acknowledgements The authors are grateful to the staff of the Mongolian National University of Medical Sciences, University of Veterinary Medicine, Vienna, for their cooperation and assistance during the research. Thanks are also due to Mr. Nyamsuren Batsaikhan, Department of Biology, National University of Mongolia, for his kind assistance in obtaining some rare literatures. Research works of M. Narankhajid and Anja Joachim were supported by the Eurasia Pacific Administrative office within the OeAD, Austria.

Authors' contributions AJ and GD conceived and designed the study and critically revised the manuscript. $\mathrm{MN}, \mathrm{GD}, \mathrm{BB}$ and SWA performed the experiments, analysed the data and drafted and revised the manuscript. $\mathrm{CY}, \mathrm{AG}$ and JB provided samples of ticks from field survey. All authors have approved the final manuscript.

Funding Information Open access funding provided by University of Veterinary Medicine Vienna.

\section{Compliance with ethical standards}

Conflict of interests The authors declare that they have no competing interests.

Open Access This article is distributed under the terms of the Creative Commons Attribution 4.0 International License (http:// creativecommons.org/licenses/by/4.0/), which permits unrestricted use, distribution, and reproduction in any medium, provided you give appropriate credit to the original author(s) and the source, provide a link to the Creative Commons license, and indicate if changes were made.

\section{References}

Altangerel K, Battsetseg B, Battur B, Sivakumar T, Batmagnai E, Javkhlan G, Tuvshintulga B, Igarashi I, Matsumoto K, Inokuma H, Yokoyama N (2011) The first survey of Theileria orientalis infection in Mongolian cattle. Vet Parasitol 182:343-348
Altangerel K, Sivakumar T, Battsetseg B, Battur B, Ueno A, Igarashi I, Yokoyama N (2012) Phylogenetic relationships of Mongolian Babesia bovis isolates based on the merozoite surface antigen (MSA)-1, MSA-2b, and MSA-2c genes. Vet Parasitol 184:309-316

Alvarado-Rybak M, Solano-Gallego L, Millán J (2016) A review of piroplasmid infections in wild carnivores worldwide: importance for domestic animal health and wildlife conservation. Parasit Vectors 9(1):538

Avarzed À, De Waal DT, Igarashi I, Saito À, Oyamada Ò, Toyada Y, Suzuki N (1997) Prevalence of equine piroplasmosis in Central Mongolia. Onderstepoort J Vet Res 64:141-145

Baasandavga U, Badrakh B, Damdindorj T, Damdin O, Lkhagvasuren P, Ulaankhuu U, Baatar U (2017) Geographical distribution of tickborne encephalitis and its vectors in Mongolia 2005-2016. Cent Asian J Med Sci 3(3):250-258

Battsetseg B, Luce S, Xuan X, Claveria F, Byambaa B, Battur B, Boldbaatar D, Batsukh Z, Khaliunaa TS, Battsetseg G, Igarashi I, Nagasawa H, Fujisaki K (2002) Detection of equine Babesia spp gene fragments in Dermacentor nuttalli Olenev 1929 infesting Mongolian horses, and their amplification in egg and larval progenies. J Vet Med Sci 64:727-730

Battsetseg B, Xuan X, Ikadai H, Bautista JL, Byambaa B, Boldbaatar D, Battur B, Battsetseg G, Batsukh Z, Igarashi I, Nagasawa H, Mikami T, Fujisaki K (2001) Detection of Babesia caballi and Babesia equi in Dermacentor nuttalli adult ticks. J Parasitol 31:384-386

Belongia EA (2002) Epidemiology and impact of coinfections acquired from Ixodes ticks. Vector-Borne Zoon Dis 2:265-273

Beugnet F, Moreau Y (2015) Babesiosis. Rev Sci Tech 34(2):627-639

Boldbaatar B, Jiang RR, von Fricken ME, Lkhagvasuren S, Nymadawa P, Baigalmaa B, Wang YW, Anderson BD, Jiang JF, Gray GC (2017) Distribution and molecular characteristics of rickettsiae found in ticks across Central Mongolia. Parasit Vectors 10:61

Boldbaatar D, Xuan X, Battsetseg B, Igarashi I, Battur B, Batsukh Z, Bayambaa B, Fujisaki K (2005) Epidemiological study of equine piroplasmosis in Mongolia. Vet Parasitol 127:29-32

Blaschitz M, Narodoslavsky-Gföller M, Kanzler M, Stanek G, Walochnik $\mathrm{J}$ (2008) Babesia species occurring in Austrian Ixodes ricinus ticks. Appl Environ Microbiol 74:4841-4846

Danchinova GA, Khasnatinov MA, Abmed D, Bataa J, Nyamdavaa P, Tserennorov D, Otgonbaatar D, Neamchy D, Khishigsuren N (2007) Fauna and ecology of ixodid ticks in Mongolia. Bull Sci Cent Russ Acad Med Sci 3(55):90-93 (in Russian)

Danchinova GA, Khasnatinov MA, Arbatskaya EV, Shoboyeva RS, Khankhareyev SS, Abmed D, Bataa J, Tserennorov D, Otgonbaatar D (2012) The spread of the tick-borne infections in the basin of Selenga River in Buryatia and Mongolia. Bull Sci Cent Russ Acad Med Sci 5(87):206-209 (in Russian)

Dash M, Biambaa B, Neronov VM (1988) The ixodid tick fauna of the Mongolian People's Republic the species distribution. Med Parasitol (Mosk) 3:37-42 (in Russian)

de Waal DT (1992) Equine piroplasmosis: a review. Br Vet J 148:6-14

de Waal, DT, van Heerden J (1994) Equine piroplasmosis in: Coetzer, JAW, Tustin, RC (Eds) Infectious Diseases of Livestock, Vol 1. Oxford University Press, New York

Duscher GG, Leschnik M, Fuehrer HP, Joachim A (2014) Wildlife reservoirs for vector-borne canine, feline and zoonotic infections in Austria. Int J Parasitol Parasites Wildl 4(1):88-96

Estrada-Peña A, Jongejan F (1999) Ticks feeding on humans: a review of records on human-biting Ixodoidea with special reference to pathogen transmission. Exp Appl Acarol 23:685-715

Filippova NA (1985) Taiga tick, Ixodes persulcatus Schulze (Acarina, Ixodidae): morphology, systematics, ecology, medical importance. Nauka, Leningrad, p 416 [in Russian]

Fomenko NV, Stronin OV, Khasnatinov MA, Danchinova GA, Bataa J, Gol'tsova NA (2009) The heterogeneity of the ospa gene of Borrelia 
garinii and Borrelia afzelii in western Siberia and Mongolia. Mol Gen Microbiol Virusol 4:18-22 [in Russian]

Frey S, Mossbrugger I, Altantuul D, Battsetseg J, Davaadorj R, Tserennorov D, Buyanjargal T, Otgonbaatar D, Zöller L, Speck S, Wölfel R, Dobler G, Essbauer S (2012) Isolation, preliminary characterization, and full-genome analyses of tick-borne encephalitis virus from Mongolia. Virus Genes 45(3):413-425

Ginsberg HS (2008) Potential effects of mixed infections in ticks on transmission dynamics of pathogens: comparative analysis of potential effects of mixed infections in ticks on transmission dynamics of pathogens: comparative analysis of published records. Exp Appl Acarol 46:29-41

Hong SH, Anu D, Jeong Y II, Abmed D, Cho SH, Lee WJ, Lee SE (2014) Molecular detection and seroprevalence of Babesia microti among stock farmers in Khutul city, Selenge province, Mongolia. Korean J Parasitol 52:443-447

Imhoff M, Hagedorn P, Schulze Y, Hellenbrand W, Pfeffer M, Niedrig M (2015) Review: sentinels of tick-borne encephalitis risk. Ticks Tick Borne Dis 6(5):592-600

Irwin PJ (2010) Canine babesiosis. Vet Clin North Am Small Anim Pract 40(6):1141-1156

Iwabu-Itoh Y, Bazartseren B, Naranbaatar O, Yondonjamts E, Furuno K, Lee K, Sato K, Kawabata H, Takada N, Andoh M, Kajita H, Oikawa Y, Nakao M, Ohnishi M, Watarai M, Shimoda H, Maeda K, Takano A (2017) Tick surveillance for Borrelia miyamotoi and phylogenetic analysis of isolates in Mongolia and Japan. Ticks Tick Borne Dis $8(6): 850-857$

Jaenson TG, Hjertqvist M, Bergström T, Lundkvist A (2012) Why is tickborne encephalitis increasing? A review of the key factors causing the increasing incidence of human TBE in Sweden. Parasit Vectors $5: 184$

Jaenson TG, Värv K, Fröjdman I, Jääskeläinen A, Rundgren K, Versteirt V, Estrada-Peña A, Medlock JM, Golovljova I (2016) First evidence of established populations of the taiga tick Ixodes persulcatus (Acari: Ixodidae) in Sweden. Parasit Vectors 9(1):377

Javkhlan G, Enkhtaivan B, Baigal B, Myagmarsuren P, Battur B, Battsetseg B (2014) Natural Anaplasma phagocytophilum infection in ticks from a forest area of Selenge province, Mongolia. Western Pacific Surveillance Response J 5:21-24

Kaewmongkol G, Lukkana N, Yangtara S, Kaewmongkol S, Thengchaisri N, Sirinarumitr T, Jittapalapong S, Fenwick SG (2017) Association of Ehrlichia canis, hemotropic Mycoplasma spp and Anaplasma platys and severe anemia in dogs in Thailand. Vet Microbiol 201:195-200

Karnath C, Obiegala A, Speck S, Essbauer S, Derschum H, Scholz H, Kiefre D, Tserennorov D, Dashdavaa O, Tsogbadrakh N, Jigjav B, Pfeffer M (2016) Detection of Babesia venatorum, Anaplasma phagocytophilum and Candidatus Neoehrlichia mikurensis in Ixodes persulcatus ticks from Mongolia. Ticks and Tick-borne Dis 7:357-360

Khasnatinov M, Tserennorov D, Nymadavaa P, Tchaporgina EA, Glushenkova T, Arbatskaya E, Bataa J, Abmed D, Danchinova GA, Otgonbaatar D (2010) Tick-borne encephalitis virus in Mongolia. J Infect Dis 14:373-373

Khishigsuren N (2002) Identification keys to ticks. Proc Nat Foci Infect Dis 38:86-119 (in Mongolian)

Korenberg EI (1995) Ixodid tick-borne borrelioses (ITBBs), infections of the Lyme borreliosis group, in Russia: country report. In: Report of WHO Workshop on Lyme Borreliosis Diagnosis and Surveillance. Sanitati, Warsaw, pp 128-136

Krause PJ (2002) Babesiosis. Med Clin N Am 86:361-373

Kurtenbach K, Hanincová K, Tsao JI, Margos G, Fish D, Ogden NH (2006) Fundamental processes in the evolutionary ecology of Lyme borreliosis. Nat Rev Microbiol 4:660-669

Lee SH, Kim BJ, Kim JH, Park KH, Kim SJ, Kook YH (2000) Differentiation of Borrelia burgdorferi sensu lato on the basis of
RNA polymerase gene $(r p o B)$ sequences. J Clin Microbiol 38(7): 2557-2562

Liz JS, Sumner JW, Pfister K, Brossard M (2002) PCR detection and serological evidence for granulocytic ehrlichial infection in roe deer (Capreolus capreolus) and chamois (Rupicapra rupicapra). J Clin Microbiol 40:92-897

Loewenich FD, Stumpf G, Baumgarten BU, Rollinghoff M, Dumler JS, Bogdan C (2003) A case of equine granulocytic ehrlichiosis provides molecular evidence for the presence of pathogenic Anaplasma phagocytophilum (HGE agent) in Germany. Eur J Clin Microbiol Infect Dis 22:303-305

Masuzawa T, Masuda S, Fukui T, Okamoto Y, Bataa J, Oikawa Y, Ishiguro F, Takada N (2014) PCR detection of Anaplasma phagocytophilum and Borrelia burgdorferi in Ixodes presulcatus ticks in Mongolia. Jpn J Infec Dis 67:47-49

Mazlum Z (1968) Hyalomma asiaticum asiaticum Schulze und Schlotke 1929 its distribution, hosts, seasonal activity, life cycle and role in transmission of bovine theileriosis in Iran. Acarolgia 10(3):437-442

Munkhjargal T, Sivakumar T, Battsetseg B, Nyamjargal T, Aboulaila M, Purevtseren B, Bayarsaikhan D, Byambaa B, Terkawi MA, Yokoyama N, Igarashi I (2013) Prevalence and genetic diversity of equine piroplasms in the Tov Province, Mongolia. Infect Genet Evol $16: 178-185$

Muto M, Bazartseren B, Tsevel B, Dashzevge E, Yoshii K, Kariwa H (2015) Isolation and characterization of tick-borne encephalitis virus from Ixodes persulcatus in Mongolia in 2012. Ticks Tick Borne Dis 6:623-629

Nataliya V, Fomenko NV, Livanova L, Chernousova YA (2008) Diversity of Borrelia burgdorferi sensu lato in natural foci of Novosibirsk region. J Med Microbiol 298:1139-1148

National Statistical Office of Mongolia (2017) http://www.en.nso.mn

Ochirkhuu N, Konnai S, Odbileg R, Murata S, Ohashi K (2017) Molecular epidemiological survey and genetic characterization of Anaplasma species in Mongolian livestock. Vector-Borne Zoon Dis $17: 539-549$

Pañczuk A, Tokarska-Rodak M, Kozioł-Montewka M, Plewik D (2016) The incidence of Borrelia burgdorferi, Anaplasma phagocytophilum and Babesia microti coinfections among foresters and farmers in eastern Poland. J Vector-Borne Dis 53(4):348-354

Papageorgiou S, Battsetseg G, Kass P, Foley J (2012) Detection and epidemiology of tick-borne pathogens in free-ranging livestock in Mongolia. J Clin Exp Pathol S3:006

Parola P, Raoult D (2001) Ticks and tickborne bacterial diseases in humans: an emerging infectious threat. Clin Infec Dis 32:897-928

Petrovec M, Sixl W, Schweiger R, Mikulasek S, Elke L, Wüst G, Marth E, Strasek K, Stünzner D Avsic-Zupanc, T(2003) Infections of wild animals with Anaplasma phagocytophilum in Austria and the Czech Republic. Ann N Y Acad Sci 990:103-106

Polin H, Hufnagl P, Haunschmid R, Gruber F, Ladurner G (2004) Molecular evidence of Anaplasma phagocytophilum in Ixodes ricinus ticks and wild animals in Austria. J Clinical Microbiology 42(5):2285-2228

Raileanu C, Moutailler S, Pavel I, Porea D, Mihalca AD, Savuta G, Vayssier-Taussat M (2017) Borrelia diversity and co-infection with other tick borne pathogens in ticks. Front Cell Infect Microbiol 7:36

Rubel F, Brugger K, Pfeffer M, Chitimia-Dobler L, Didyk YM, Leverenz S, Dautel H, Kahl O (2016) Geographical distribution of Dermacentor marginatus and Dermacentor reticulatus in Europe. Ticks Tick Borne Dis 7(1):224-233

Ruegg SR, Torgerson PR, Doherr MG, Deplazes P, Böse R, Robert N, Walzer C (2006) Equine piroplasmoses at the reintroduction site of the Przewalski's horse (Equus ferus przewalskii) in Mongolia. J Wildl Dis 42(3):518-526

Ruegg SR, Torgerson P, Deplazes P, Mathis A (2007) Age-dependent dynamics of Theileria equi and Babesia caballi infections in 
southwestern Mongolia based on IFAT and/or PCR prevalence data from domestic horses and ticks. J Parasitol 134:939-947

Sawczuk M, Maciejewska A, Skotarczak B (2008) Identification and molecular characterization of Theileria sp. infecting red deer (Cervus elaphus) in northwestern Poland. Eur J Wildl Res 54:225230

Scholz HC, Margos G, Derschum H, Speck S, Tserennorov D, Erdenebat $\mathrm{N}$, Undraa B, Enkhtuja M, Battsetseg J, Otgonchimeg C, Otgonsuren G, Nymadulam B, Römer A, Thomas A, Essbauer S, Wölfel R, Kiefer D, Zöller L, Otgonbaatar D, Fingerle V (2013) High prevalence of genetically diverse Borrelia bavariensis-like strains in Ixodes persulcatus from Selenge Aimag, Mongolia. Ticks Tick Borne Dis 4:89-92

Schulze P, Schlottke E (1930) Bestimmungstabellen für das Zeckengenus Hyalomma Koch $s$ str. Sitzungsber Abhandl Naturforsch Gesell Rost 2:32-46

Scoles GA, Ueti MW (2015) Vector ecology of equine piroplasmosis. Annu Rev Entomol 60:561-580

Sivakumar T, Altangerel K, Battsetseg B, Battur B, Aboulaila M, Munkhjargal T, Yoshinari T, Yokoyama N, Igarashi I (2012) Genetic detection of Babesia bigemina from Mongolian cattle using apical membrane antigen-1 gene-based PCR assay. Vet Parasitol 187:17-22

Sloboda M, Jirk M, Luke D, Qablan M, Batsukh Z, Fiala I, Horin P, Modrý D, Luke J (2011) A survey for piroplasmids in horses and bactrian camels in North-Eastern Mongolia. Vet Parasitol 179:246249

Smrdel KS, Tozon N, Duh D, Petrovec M, Avsic Zupanc T (2009) Diversity of groESL sequences of Anaplasma phagocytophilum among dogs in Slovenia. J Clin Microbiol Infect 15:79-80

Solano-Gallego L, Sainz Á, Roura X, Estrada-Peña A, Miró G (2016) A review of canine babesiosis: the European perspective. Parasit Vectors 9(1):336

Stefanoff P, Pfeffer M, Hellenbrand W, Rogalska J, Rühe F, Makówka A, Michalik J, Wodecka B, Rymaszewska A, Kiewra D, BaumannPopczyk A, Dobler G (2013) Virus detection in questing ticks is not a sensitive indicator for risk assessment of tick-borne encephalitis in humans. Zoonoses Public Health 60(3):215-226

Stone BL, Tourand Y, Brissette CA (2017) Brave new worlds: the expanding universe of Lyme disease. Vector Borne Zoonotic Dis 17(9):619-629

Strnad M, Hönig V, Růžek D, Grubhoffer L, Rego ROM (2017) Europewide meta-analysis of Borrelia burgdorferi sensu lato prevalence in questing Ixodes ricinus ticks. Appl Environ Microbiol 83(15): e00609-e00617. https://doi.org/10.1128/AEM.00609-17

Stuen S, Granquist EG, Silaghi C (2013) Anaplasma phagocytophiluma widespread multi-host pathogen with highly adaptive strategies. Front Cell Infect Microbiol 3:31

Suarez CE, Noh S (2011) Emerging perspectives in the research of bovine babesiosis and anaplasmosis. Vet Parasitol 180(1-2):109-125
Sumner JW, Nicholson WL, Massung RF (1997) PCR amplification and comparison of nucleotide sequences from the groESL heat shock operon of Ehrlichia species. J Clin Microbiol 35:2087-2092

Swanson SJ, Neitzel D, Reed KD, Belongia EA (2006) Coinfections acquired from Ixodes ticks. Clin Microbiol Rev 19:708-727

Tarav M, Tokunaga M, Kondo T, Kato-Mori Y, Hoshino B, Dorj U, Hagiwara K (2017) Problems in the protection of reintroduced Prezewalski's horses (Equus ferus przewalskii) caused by piroplasmosis. J Wildlife Dis 53:911-915

Tuvshintulga B, Battsetseg B, Battur B, Myagmarsuren P, Narantsatsral S, Sivakumar T, Igarashi I, Inoue N, Yokoyama N (2015) First detection of Babesia venatorum (EU1) in Ixodes persulcatus ticks in Mongolia. J Protozool Res 25:29-37

Tuvshintulga B, Sivakumar T, Battsetseg B, Narantsatsral S, Enkhtaivan B, Battur B, Hayashida K, Okubo K, Ishizaki T, Inoue N, Igarashi I, Yokoyama N (2016) The PCR detection and phylogenetic characterization of Babesia microti in questing ticks in Mongolia. Parasitol Int 64:527-532

Valarcher JF, Hägglund S, Juremalm M, Blomqvist G, Renström L, Zohari S, Leijon M, Chirico J (2015) Tick-borne encephalitis. Rev Sci Tech 34(2):453-66

von Fricken ME, Lkhagvatseren S, Boldbaatar B, Nymadawa P, Weppelmann TA, Baigalmaa B, Anderson BD, Reller ME, Lantos PM, Gray GC (2018) Estimated seroprevalence of Anaplasma spp and spotted fever group Rickettsia exposure among herders and livestock in Mongolia. Acta Trop 177:179-185

Walder G, Lkhamsuren E, Shagdar A, Bataa J, Batmunkh T, Orth D, Heinz FX, Danichova GA, Khasnatinov MA, Wurzner R (2006) Serological evidence for tick-borne encephalitis, borreliosis, and human granulocytic anaplasmosis in Mongolia. J Med Microbiol 296:69-75

Wei F, Song M, Liu H, Wang B, Wang S, Wang Z, Ma H, Li Z, Zeng Z, Qian J, Liu Q (2016) Molecular detection and characterization of zoonotic and veterinary pathogens in ticks from northeastern China. Front Microbiol 7:1913

Wise LN, Kappmeyer LS, Mealey RH, Knowels DP (2013) Review of equine prioplasmosis. J Vet Intern Med 27:1334-1346

Wu XB, Na RH, Wei SS, Zhu JS, Peng HJ (2013) Distribution of tickborne diseases in China. Parasites and Vectors 6:119

Xuan X, Igarashi I, Avarzed A, Ikadai H, Inoue N, Nagasawa H, Fujisaki K, Toyoda Y, Suzuki N, Mikami T (1998) Diagnosis of Babesia caballi infection in horses by polymerase chain reaction. $\mathrm{J}$ Protozool Res 8:85-89

Yoshinari T, Sivakumar T, Asada M, Battsetseg B, Huang X, Lan DTB, Inpankaew T, Ybañez A, Alhassan A, Thekisoe OMM, De Macedo ACC, Inokuma H, Igarashi I, Yokoyama N (2013) A PCR based survey of Babesia ovata in cattle from various Asian, African and south American countries. J Vet Med Sci 75:211-212

Zhang SH (2012) The latest research progress of tick and the tick-borne diseases. Anhui J Prevent Med 18:45-48 